\title{
Ferruginous groundwaters as a source of $P$, Fe, and DIC for coastal waters of the southern Baltic Sea: (Isotope) hydrobiogeochemistry and the role of an iron curtain
}

\author{
Marko Lipka $^{1}$, Michael E. Böttcher ${ }^{1}$, Zijun $\mathrm{Wu}^{1,4}$, Jürgen Sültenfuß ${ }^{2}$, Anna-K. Jenner ${ }^{1}$, \\ Julia Westphal $^{1}$, Olaf Dellwig ${ }^{1}$, Peter Escher ${ }^{1,5}$, Iris Schmiedinger ${ }^{1}$, Vera Winde ${ }^{1,6}$, Ulrich \\ Struck $^{3}$ \\ ${ }^{1}$ Geochemistry \& Isotope BioGeoChemistry Group, Leibniz Institute for Baltic Sea Research \\ (IOW), Warnemünde, FRG; ${ }^{2}$ Environmental Physics Department, Bremen University, \\ Bremen, FRG; ${ }^{3}$ Natural History Museum, Berlin, FRG; ${ }^{4}$ State Key Laboratory of Marine \\ Geology, Tongji University, Shanghai, PRC; ${ }^{5}$ current address: Ecoandmore, Freiburg, FRG \\ ${ }^{6}$ current address: LUBW, Lake Research Institute (ISF), Langenargen, FRG
}

\begin{abstract}
We report first results from a study on water and element exchange across the land-ocean boundary at the southern Baltic Sea. The focus is set on ferruginous fresh ground waters escaping at the shore line, flowing in air contact before entering a subterranean mixing zone with brackish Baltic Sea water. The present study combines the results from multiple sampling campaigns that investigated the composition of several springs as well as the surface and subsurface development of fresh waters on the way to the Baltic Sea. This is achieved by a combination of hydro- and solid-phase geochemical and stable isotope measurements with ground water dating. Results are compared to the composition of groundwaters recovered from wells in the catchment area and the local isotope meteoric water line developed for Warnemünde. The spring water is shown to be impacted by the dissolution of biogenic carbon dioxide and marine carbonate as well as the oxidation of pyrite in glacial sediments. Dating yields a surprisingly high diversity between some closely associated springs with average ages of about 25 to 32 years, but different mixing proportions with older tritium-free ground-water.
\end{abstract}

\section{INTRODUCTION}

Fresh waters, like rivers, streams or submarine ground water discharge (SGD), entering the estuarine and coastal areas, provide important pathways for element and water flow at the land-ocean transition. Since these waters may be enriched in (micro) nutrients, metals, and dissolved inorganic carbon (DIC) (Knee \& Paytan 2010; Winde et al. 2014; Donis et al. 2017; Böttcher et al. 2018) the input is linked to potential societal issues, like eutrophication, the development of algal blooms and hypoxia, the increase or decrease of the buffer capacity of coastal waters (associated to green-house effect, as well as ocean acidification), to mention a few.

In the present study we focused on ferruginous fresh groundwaters emerging at the shore line of the southern Baltic Sea (close to Kühlungsborn) and their role as sources for $\mathrm{P}, \mathrm{DIC}, \mathrm{SO}_{4}{ }^{2-}$ and metals and the factors impacting the fate in the transition zone. We apply a multi-tracer combination of hydrogeochemical with stable isotope $(\mathrm{H}, \mathrm{C}, \mathrm{O}, \mathrm{S})$ analysis and the dating of the springs (tritium and noble gases) to define the sources of fresh water and dissolved elements, processes affecting the surface water in contact with the atmosphere (absorption of oxygen, desorption of carbon dioxide) and upon subterranean mixing with brackish Baltic 
Sea water. The precipitation of FeOOH ('iron curtain') at the sediment surface and in the sediments acts as a temporal trap for dissolved phosphate and the (temporal?) impact by the activity of iron-oxidizing bacteria is indicated. The results are further compared to the composition of groundwaters sampled from drinking and observation wells near the Baltic Sea coastline as well as the local isotopic meteoric water line established for Warnemünde.

\section{METHODS}

Water samples from the springs and the stream, underlying pore waters, as well as the water column of the Baltic Sea were taken and analyzed following established procedures (Kowalski et al. 2012; Winde et al. 2014). Water aliquots were immediately filtered ( 0.45 $\mu \mathrm{m}$ membrane filters) for further analyses by ICP-OES (Thermo iCAP 6300 Duo, Thermo Fisher Scientific) and a QuAAtro nutrient analyzer (SEAL Analytical). ICP-OES and SEMEDX were used to analyze the composition of acidic sediment extracts and the microstructure of $\mathrm{FeOOH}$ precipitates, respectively. Measurements of tritium, helium isotopes and neon followed Sueltenfuß et al. (2009). Stable C and S isotopes were analyzed with a Thermo Finnigan MAT253 mass spectrometer attached to a Gasbench II or and Thermo elemental Flash analyzer. Stable water $(\mathrm{H}, \mathrm{O})$ isotope measurements were conducted by means of Picarro CRDS systems. All stable isotope results are given in the conventional $\delta$ notation (equivalent to milli Urey) versus respective international standards. Hydrogeochemical results were additionally subjected to a thermodynamic analysis via PHREEQC.

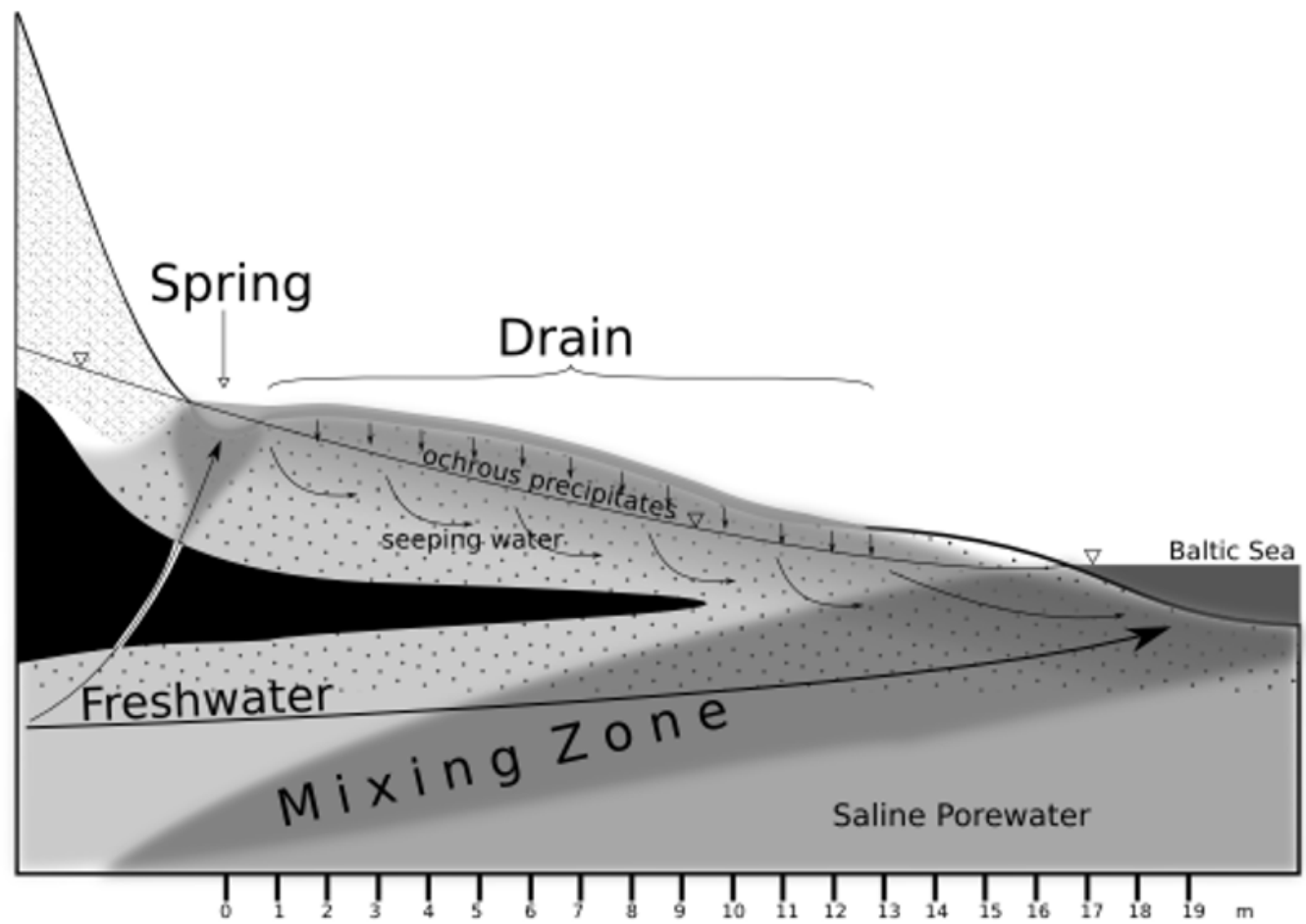

Figure 1. Sketch showing the generation of ferruginous ground water springs and a the development of a subterrestrial mixing zone for SGD with Baltic Sea water at the shore line. Black: Fissured clayish layer. 


\section{RESULTS AND DISCUSSION}

\section{Spatial and seasonal dynamics of spring waters}

Ferruginous fresh groundwaters springs occuring at the shore line of the southern Baltic Sea were investigated on a seasonal base for a period of more than 7 years. The geostationary springs emerge in small pits of up to about $70 \mathrm{~cm}$ diameter with up to $15 \mathrm{~cm}$ water depth. The shape of the pits and the stream beds, in particular closer to the Baltic Sea water line varied considerably due to regular sediment re-structuring driven by wind and wave activity. The outflowing ground waters are oxygen-free, but rich in dissolved iron, sulfate, phosphate and dissolved inorganic carbon (DIC; Fig.2). They showed constantly minor relative differences between springs through the years, with an exception for redox-sensitive elements like $\mathrm{Fe}^{2+}$ that are further impacted by storm-related redistribution of surface sediments.
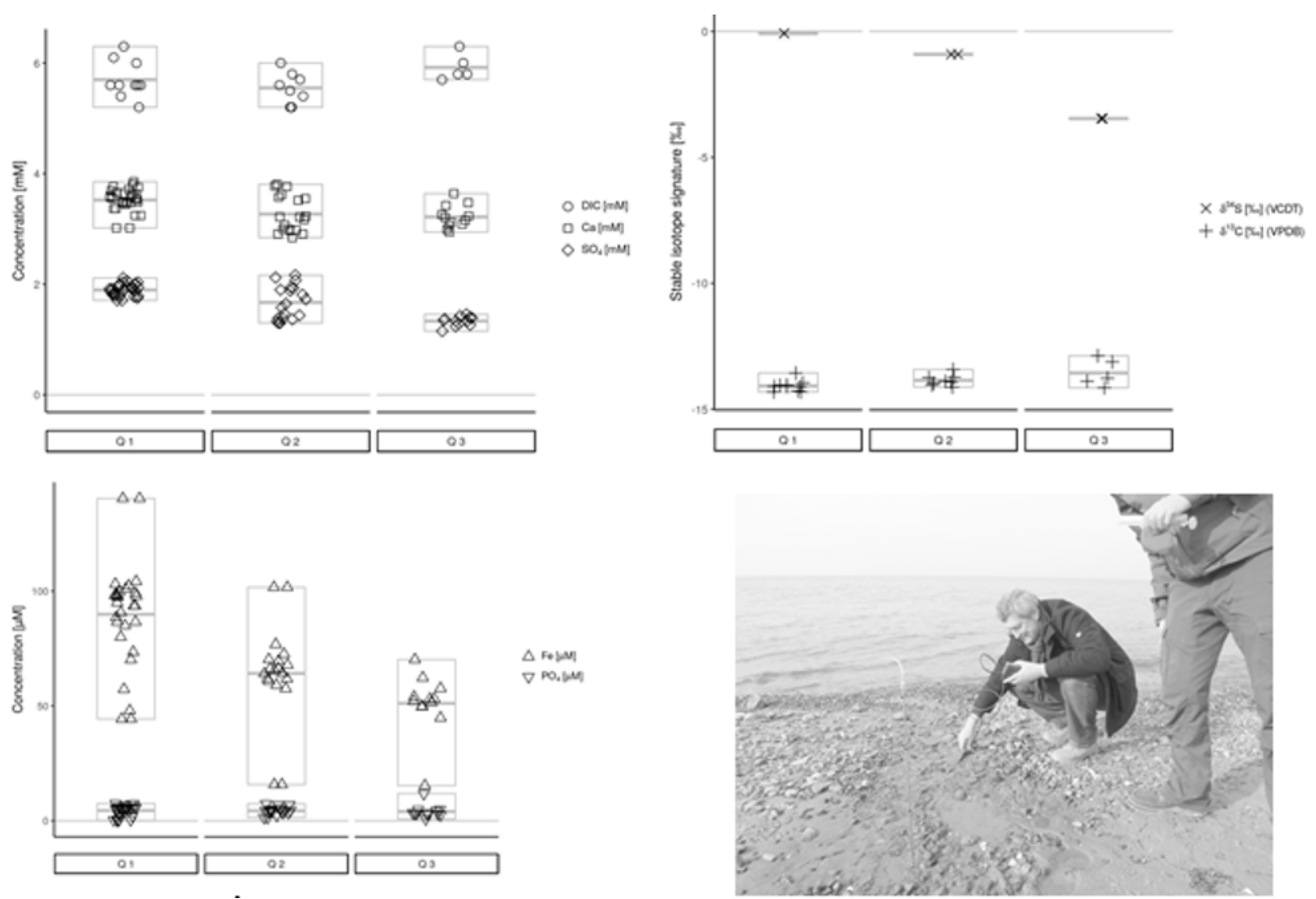

Figure 2. A-C Temporal dynamics of selected dissolved major and minor components and the stable isotope composition of DIC and $\mathrm{SO}_{4}$ for three springs waters. D: In-situ measurements at spring $Q 1$ during winter time.

Tritium-noble gas dating indicates ages between 25 and 35 years, with surprisingly high different mixing contributions from older tritium-free waters. This indicates a high complexity of the hydrogeology of the coastal aquifers with aquifers essentially build of glacial deposits. The observed differences in ground water composition reflect heterogeneous flow path conditions (including residence times) before reaching the Baltic Sea shore line, highlighting the importance of local and regional investigations in the evaluation of the impact SGD discharge on the transport of substances (DIC, nutrients, metals) into coastal ecosystems. The hydrogeochemical and stable isotope composition 
indicates that the spring water composition is controlled by the dissolution of biogenic carbon dioxide in the unsaturated soil zone of the catchment area followed by the dissolution of marine carbonate and biogenic pyrite in the sediments building up the aquifers (e.g., Zhang et al. 2012; Donis et al. 2017).

\section{Processes impacting stream water composition in air contact}

Each springs leads to a surface run-off towards the Baltic Sea. After flowing for several meters in contact with the atmosphere, the fresh water is lost to underground drainage through the beach sands reaching a mixing zone with brackish Baltic Sea waters and finally ending as submarine ground water discharge (SGD). Surface flow is associated with the uptake of gaseous oxygen, the microbially promoted precipitation of iron oxi(hydroxi)des, adsorption of phosphate (Fig.3), the loss of isotopically light carbon dioxide into the atmosphere, and probably minor calcite precipitation. Spring waters are saturated with respect to calcite, but undersaturated with respect to other rock-forming minerals like dolomite and gypsum, turning into calcite supersaturated solutions along the surface flowpath. According to our present conceptional understanding (Fig.1) an essentially anaerobic flow path directs fresh ferruginous ground water into a mixing zone with aerobic Baltic Sea water. This leads to physico-chemical and geomicrobiological changes in the composition of the aqueous solution and the surrounding sediments. This process is superimposed by the spring waters that are modified by the precipitation of $\mathrm{FeOOH}$ and associated adsorption of phosphate and arsenic, before seeping away into the mixing zone. This iron curtain acts as a temporal sink for Fe and $\mathrm{P}$ in the coastal sediments that may be transported into the Baltic Sea ecosystem during storm events.
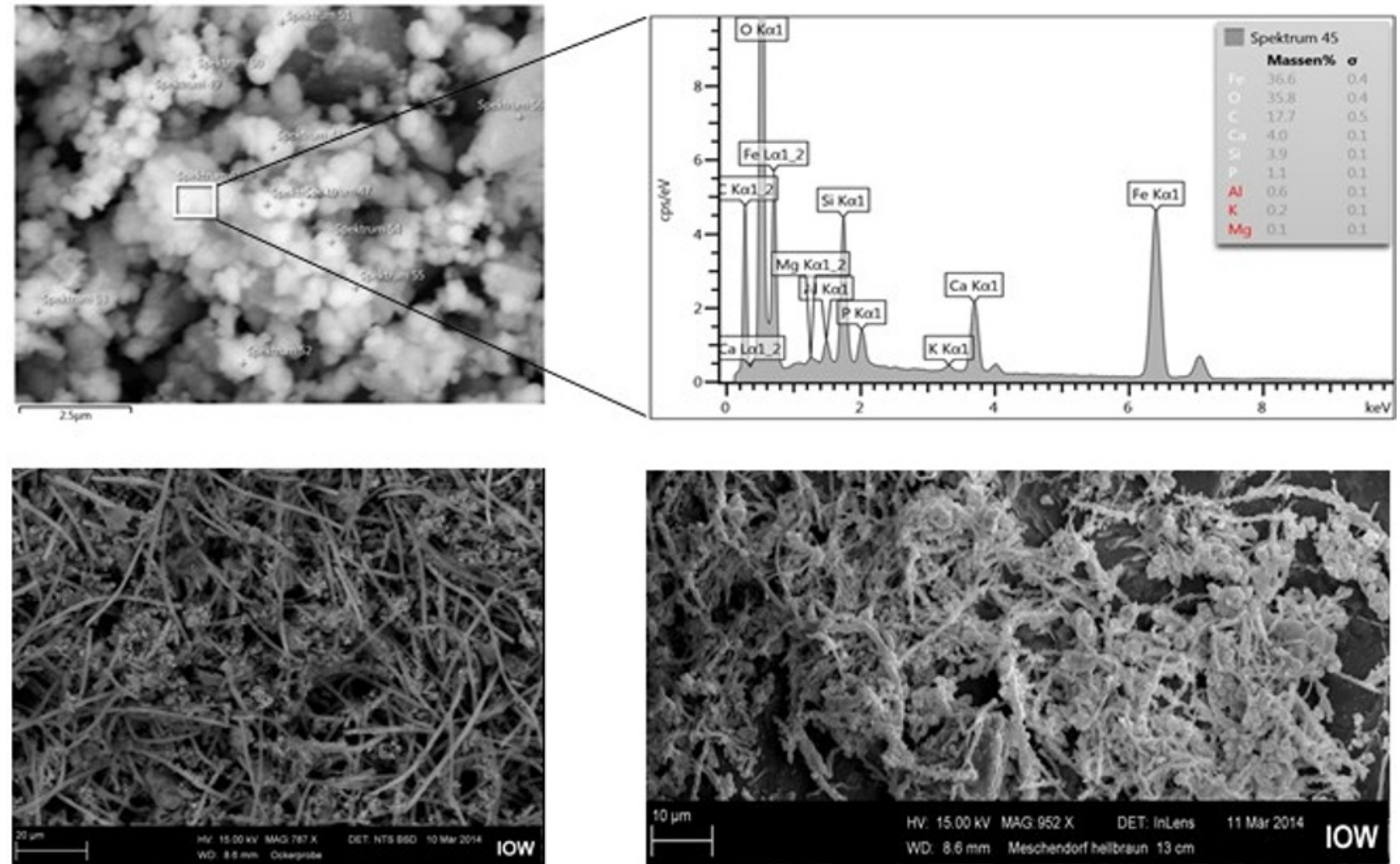

Figure 3. A and B: SEM-EDX analysis of a FeOOH sample from the surface sediments of the stream. C and D: Residual leftovers of Fe oxidizing bacteria (e.g., Leptothrix) in the stream bed. 


\section{Comparison with ground waters in the catchment and other SGD sites}

The hydrogeochemical and stable isotopic composition of the ferruginous springs is close to those found in some ground waters of Mecklenburg-Western Pomerania. Coastal pore waters in front of the Hütelmoor area are impacted by subterrestril freshening due to SGD originating from the rewetted peatland. The estimated composition of this fresh water component differs substantially from the springs found close to Kühlungsborn, likely due to a substantial overprint by early diagenetic reactions taking place in the marine sediments and a hydrological cycle in the peatland that may differ from the one in the catchment of the ferruginous springs.

\section{ACKNOWLEDGEMENTS}

This study was partly conducted within the framework of the Research Training Group 'Baltic TRANSCOAST' funded by the DFG (Deutsche Forschungsgemeinschaft) under grant number GRK 2000 (www.baltic-transcoast.uni-rostock.de). The research was further supported by BMBF within the BONUS $^{+}$project AMBER, and Leibniz IOW. Thanks are due to R. Bahlo, A. Köhler, and I. Scherff for technical support. This is Baltic TRANSCOAST publication no. GRK2000/0009.

\section{REFERENCES}

Böttcher M.E., U. Mallast, G. Massmann, N. Moosdorf, M. Müller-Petke, and H. Waska. 2018. Coastal-Groundwater interfaces (submarine groundwater discharge). In (Krause S, ed.) Ecohydrological Interfaces, Wiley Science, in press.

Donis D., F. Janssen, B. Liu, F. Wenzhöfer, O. Dellwig, P. Escher, A. Spitzy, and M.E. Böttcher. 2017. Biogeochemical impact of submarine ground water discharge on coastal surface sands of the southern Baltic Sea. Est. Coast. Shelf Sci., 189: 131-142.

Knee K.L., and A. Paytan. 2011. Submarine groundwater discharge: A source of nutrients, metals, and pollutants to the coastal ocean. In: Wolanski E., D.S. McLusky. (eds.) Treatise on Estuarine and Coastal Science, 4: 205-233.

Kowalski N., O. Dellwig, M. Beck, M. Grunwald, T. Badewien, H.J. Brumsack, J.E.E. van Beusekom, and M.E. Böttcher .2012. A comparative study of manganese dynamics in pelagic and benthic parts of two tidal systems of the North Sea. Estuar. Coast. Shelf Sci., 100: 3-17.

Sültenfuß, J., M. Rhein, and W. Roether. 2009. The Bremen Mass Spectrometric Facility for the measurement of helium isotopes, neon, and tritium in water. Isotopes in Environmental and Health Studies, 45(2), 1-13.

Winde, V., M.E. Böttcher, P. Escher, P. Böning, M. Beck, G. Liebezeit, and B. Schneider. 2014. Tidal and spatial variations of $\mathrm{DI}^{13} \mathrm{C}$ and aquatic chemistry in a temperate tidal basin during winter time. Journal of Marine Systems, 129: 394-402.

Zhang Y.-C., C.P. Slomp, H.P. Broers, H.F. Passier, M.E. Böttcher, E.O. Omoregie, J.R. Lloyd, D.A. Polya, and P. van Cappellen. 2012. Geochemical and microbial signatures of denitrification linked to pyrite oxidation in a sandy aquifer. Chem. Geol., 300-301: 123-132.

Contact Information: Michael E. Böttcher, Geochemistry \& Isotope Biogeochemistry Group, Marine Geology Department, Leibniz IOW, D-18119 Warnemünde, FRG, email: michael.boettcher@io-warnemuende.de. 